\title{
Research on Operation Mechanism of Regional Vocational Education Group under Perspective of Secondary and Higher Vocational Education Connection
}

\author{
Chunmei Lu, Hengshi Huang \\ Guangxi International Business Vocational College, Nanning Guangxi 530007
}

Key words: Secondary and higher vocational education connection, Regional vocational education group, Operation mechanism.

\begin{abstract}
Secondary and higher vocational education connection refers to promotion of harmonious development of secondary and higher vocational education according to the requirement of constructing modern vocational education system so as to cultivate high-end talents who can give play to basic functions and leading role. Its function is especially prominent in modern society. Regional vocational education group has played a very important role in vocational education in recent years. This paper studies and analyzes operation mechanism of regional vocational education group under the perspective of secondary and higher vocational education connection for reference.
\end{abstract}

\section{Introduction}

Under the background of school running by vocational education group in recent years, many regional vocational education groups spring up in many places. There are also superior vocational education groups with large scale and high teaching quality. There are 1048 vocational education groups and 46000 member units nationwide, including 7200 secondary vocational schools, 950 higher vocational schools, 180 universities, 1680 industrial associations, 23500 enterprises, over 1630 government departments, 920 scientific research institutions and 1450 other institutions. Opinions on Deeply Promoting School Running by Vocational Education Group issued by the Ministry of Education in 2014 proposed that by 2020, participation rate of vocational schools in collectivized school running will further improve. The enterprises above designated scale which participate in collectivized school running will reach certain proportion. 300 backbone vocational education groups with demonstration function will be built preliminarily. Some vocational education groups which consist of state-owned enterprises and leading enterprises in the industries will be built. The situation of fusing education chain and industry chain will basically form. Even so, many employment units will suffer the awkward situation of labor shortage annually. Many graduates who have received higher education cannot find a job. Employment form becomes increasingly severe. The situation where employees lack work and enterprises lack employees becomes increasingly prominent. This is because vocational education mechanism has defects and cannot well take into account of all-round development of ideological education and vocational skills. The entire quality of graduates cannot keep pace with era development and demand of employment units. Thus, it is imperative to improve operation mechanism of vocational education group and drive secondary and higher vocational education connection.

\section{Development situating of secondary and higher vocational education connection.}

\section{Most graduates are anxious to enter the society to work, which restricts vocational education development}

Although secondary and higher vocational education connection has been promoted continuously in recent years, it is still at a low level. Only few people can continue to receive higher vocational education after receiving secondary vocational education. For example, before Guangxi drove 
vocational education collectivization on a large scale in 2013, the index of enrolling students from secondary vocational schools by higher vocational schools was 25700. 14000 students were enrolled, and 11000 students registered. The plan completion rate and register rate were $54 \%$ and $76 \%$ respectively. For many students, graduation is the end point of vocational education, regardless of higher vocational education or secondary vocational education. Promotion examination of vocational education puts particular emphasis on general knowledge courses. In recent years, some vocational colleges have added skill examination and set independent enrollment plan. In this way, more students can learn from others' strong points to offset their weaknesses and enter higher colleges for further study. But most vocational education groups still take general knowledge courses as the examination standard. This is an institutional defect.

\section{Teaching system of secondary and higher vocational education connection has defects}

Secondary and higher vocational education connection system is not sound. Course teaching difference of secondary and higher vocational education is not obvious. These are two important causes for low development level of secondary and higher vocational education connection. The differences between secondary vocational education and higher vocational education mainly lie in object of education, education level, and training objective. Higher vocational and technical education is the high level of vocational and technical education. It extends and improves secondary vocational education. However, many contents are repeated in secondary and higher vocational education connection, so much time is wasted. Source setting is chaotic in many places. Students also encounter selection trouble. Besides, many vocational education groups are unwilling to invest much in practice. Thus, practice conditions for students receiving vocational education are general. Students’ learning initiative also declines.

\section{Conceptual problems exists generally}

Traditional concept and backward view such as the idea of uselessness of study is a major factor hindering educational development. This is also embodied in secondary and higher vocational education connection. Many parents plan to let their children to receive education or training in vocational and technical schools or regional vocational education group in order to let them be independent and earn money faster. Many students and especially the students in remote rural area are willing to accept such arrangement. They receive vocation education in order to near money as early as possible. They generally consider it is unnecessary to receive education again. This results in many problems. Outstanding problems include the following: unbalanced talent supply; "the sole purpose is to get a diploma”; low quality of employees and poor working enthusiasm; immature technical ability etc.

\section{Function of regional vocational education group in secondary and higher vocational education connection}

Secondary and higher vocational education connection is an inexorable trend. Building regional vocational education group is an important approach to achieve effective connection of secondary and higher vocational education. Firstly, regional vocational education group generally owns certain financial resources, so it can better set up platforms for students' practice and cooperate with some employment units. This needs national policy support. Secondly, through the guidance of some model schools, numerous excellent secondary and higher vocational education schools as well as employment units can form vocational education group. In this way, a better policy environment can usually be gained for vocational education so as to promote sustainable development of secondary and higher vocational education. Since regional vocational education group is often closed to local main industries and demand of employment units in terms of education setting, graduates can start to work very soon. If regional vocational education group takes high-end technical talents as the core 
and common technical talents as assistance, huge effect will be generated. Meanwhile, valuable experience can be offered for secondary and higher vocational education connection.

In developed countries, education plays a crucial role for economic development. Vocational education in each region can cultivate many technical talents who own distinct characteristics and comply with the demand of local talent market. In secondary and higher vocational education connection implemented in China, regional vocational education group can boost the contribution of vocational education to economic development and improve development level of vocational education industry. High-quality talents with high professional skills and professional quality can be cultivated through combining theoretical knowledge with practical work experience of group. Vocational education group can improve students' comprehensive abilities, accelerate its development and boost education level and teaching quality through multi-cooperation. In this way, local talent demand can be met, and graduates' employment problem can be better solved. Besides, secondary and higher vocational education connection and all-win can be achieved step by step.

Regional vocational education group also has a great advantage, i.e. enrollment, management, teaching, skill training, theory, practice and employment can be effectively connected. This can avoid students' inadaptation to employment units, and can achieve co-construction and sharing of vocational education resources and being convenience for learning from each other.

\section{Operation mechanism of regional vocational education group}

\section{Optimize organization and improve quality of school running}

Current regional vocational education group is mainly managed by administrative body, including project office, supervision office and secretariat. Vocational education, its development and research should be managed by special educational administration institution. It is suggested that special practice platform should be established for students' practical training, and more practice and training opportunities should be offered for students so as to enhance their application ability and optimize quality of school running. If possible, vocational education group can let students feel different environment through multi-cooperation. This has very good effect on improving students' adaptive capacity to environment. In addition, vocational education group should expand enrollment so as to train sufficient talents, improve its operation ability, provide authentic learning atmosphere for students and let them better adapt to their work.

\section{Issue corresponding policy and create favorable environment}

The government should attach importance to the function of regional vocational education group on secondary and higher vocational education connection, issue some preferential policies and create favorable policy environment to support vocational education group, such as policy convenience and economic support. Besides, the government should do propaganda work well and especially should do propaganda work and ideological education work well in underdeveloped area and remote rural area. The people in these areas should be mobilized to join in vocational education. In this process, local people should understand actual significance of this action. This has great significance for driving secondary and higher vocational education connection and developing regional vocational education group.

\section{Improve vocational education system and combine multiple modes}

On the one hand, teaching content should be optimized. Except providing practice and training for students to let them own solid professional skills, basic knowledge teaching should be carried out to let them own basic theoretical knowledge. In this way, secondary education can make students prepare for receiving higher vocation. Higher vocation can let students own better professional quality and handling ability. 
On the other hand, classified course setting should be optimized to better train students' practical application ability. In the optimization process, it is required to depend on vocational education group and local conditions to construct course system for different student groups according to different features of secondary and higher vocational education.

Finally, different professional courses should be set up according to local conditions. Some excellent enterprises may be invited to participate in writing teaching materials for vocational education and give vocational education lectures to speed up secondary and higher vocational education connection and improve students’ professional quality and enthusiasm.

\section{Conclusion}

In China, secondary and higher vocational education connection is still in the development stage. Regional vocational education group plays a very important role in secondary and higher vocational education connection. This not just needs national policy and environment support, but also needs exploration, research and deep analysis of education workers. Besides, the input of vocational education group should be combined with secondary and higher vocational education connection, and multi-cooperation should be implemented to achieve co-construction and sharing of vocational education resources. In this way, secondary and higher vocational education connection can be achieved, and vocational education can better serve for students, economy and society.

\section{Acknowledgements}

This paper is a phased result of special research topic about collectivized school running of Guangxi vocational education in "the 12th Five-year Plan" of Guangxi educational science (Project No.: 2014JD306)

\section{References}

[1] Liu Xuping, Exploration of current situation and main problems of secondary and higher vocational education connection. Journal of Jiamusi Vocational Institute, 2015(5).

[2] Xu Jing, Study on operation mechanism of regional vocational education group under perspective of secondary and higher vocational education connection. Contemporary Educational Science, 2014(3):62-64.

[3] Liang Tiantian, Liu Yanghua, Yang Yongliang, Research on secondary and higher vocational education connection based on vocational education group. China Adult Education, 2015(19):90-92.

[4] Jing Daihe, Zhou Yufeng, Achieving organic connection of secondary and higher vocational education based on regional vocational education group. Education for Chinese After-school, 2011(20):125-126.

[5] Dong Dakui, Wang Ying, Han fang, Study on effectiveness of secondary and higher vocational education connection under background of school running by vocational education group. Liaoning Higher Vocational Technical Institute Journal, 2014(1):1-4.

[6] JZC[2011] No.9 Opinions of Ministry of Education on Promoting Harmonious Development of Secondary and Higher Vocational Education.

[7] Special website of school running by nationwide vocational education group http://www.zjjtw.net/show.asp?id=842

[8] 2014 Annual Quality Report on Guangxi Higher Education. Education Department of Guangxi Zhuang Autonomous Region, 2014 (1) 